The

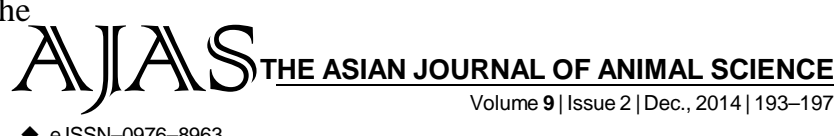

DOI : 10.15740/HAS/TAJAS/9.2/193-197

Visit us | www.researchjournal.co.in "S

A REVIEW

\title{
Use of milk by-product (whey) for preparation of beverages
}

\author{
J.N. KHEDKAR, D.M. CHOUDHARI, B.K. PAWAR AND V.S. KADAM
}

Author for Correspondence -

\section{B.K. PAWAR}

Department of Animal Science and Dairy Science, College of Agriculture, PUNE (M.S.) INDIA

See end of the article for

Coopted authors'

\begin{abstract}
Whey is the serum or watery part of the milk that remains after separation of curd that results from the acid or proteolytic enzyme mediated co-agulation of milk. It is major by product of dairy industries manufacturing products like cheese, channa, paneer, chakka and casein. Major source of whey is in the form the production of channa, paneer and Shrikhand production. This is mostly thrown away as a waste, which creates environmental pollution. Utilization of nutritious solids and their therapeutic importance, it needs to convert whey into various beverages. The whey derived from milk is cheaply renewed in to different types of fruit based whey beverages e.g. kokum juice, pineapple flavour juice, kinnow RTS beverage, mango based RTS, guava pulp, chocolate drink etc. and fermented whey beverages and sport drinks by addition of different fruits, nuts and flavours. Further, environmental effluence and nutritious solids loses through whey would be minimized by preparing such a different whey beverages, which plays pivotal role in human nutrition. They are also being used as meal replacement for people as a healthy alternative to fast food. Such various types of beverages have been found to be highly acceptable soft drinks by the consumers. In addition, there is need to educate the consumers with the aim to consume the whey and whey based beverages containing addition of different fruits, nuts and flavour resources in particular. Through this, the consumers may attract towards such products thereby the one can increase the market to the above referred dairy bi-products, which may also help to hasten the dairy industry physically monitory benefits.
\end{abstract}

KEY WORDS...... Milk, Whey, Beverages

HOW TO CITE THIS ARTICLE - Khedkar, J.N., Choudhari, D.M., Pawar, B.K. and Kadam, V.S. (2014). Use of milk by-product (whey) for preparation of beverages . Asian J. Animal Sci., 9(2) : 193-197.

ARTICLE CHRONICLE - Received : 14.04.2014; Accepted : 25.11.2014 